\title{
University of Leeds: New Physics Building.
}

THE new physics building of the University of 1 Leeds represents part of the rebuilding scheme made possible by generous donations from the public during the past several years. It replaces the old 'sheds', a temporary glass-roofed structure put up some twenty years ago, and part of one of the original wings in the occupation of the Department of Physics, but under the new scheme destined for demolition. These old laboratories had long been inadequate for their purpose and more than uncomfortable in use. The lecture room accommodation was scanty, the teaching laboratories weather-swept, and the research rooms unfortunately placed.

The new building occupies a quiet and unobtrusive site which is likely to be detached for some time to come, though it will eventually form architecturally an end link of the projected chain of stone-fronted buildings of which the chemical building and the Brotherton Library will shortly be prominent features. The cost of the physics building itself with equipment will approximate to $£ 60,000$. The architects were Lanchester, Lucas, and Lodge, of London.

So far as present needs are concerned, the Department caters for two hundred and fifty to three hundred undergraduates, including a total honours school of thirty to forty, with a research group of ten to fifteen working mostly on experimental topics. Allowing for expansion of these numbers on a conservative basis, a building of red brick, of about 35,000 square feet floor space, has been put up, comprising three floors and basement; Portland stone facing is used only on that small part which will be visible in the distance from the main road. The steel framework is specially oversize, and particular care has been taken that no internal walls support any appreciable part of the weight. Inside rearrangement can therefore be carried out in the future, if necessary, with no serious difficulty.

The workshop has been placed in a far corner of the basement, lit by an overhead glass roof and ventilated by a fan. The basement also contains certain research rooms, battery and store rooms, a special instrument test room, an acoustics laboratory, and a museum.

The entrance hall on the ground floor has been arranged to lead directly to the two main lecture rooms on one side and to the elementary laboratory on the other. This arrangement makes it unnecessary for the large numbers of studentsattending elementary lectures and laboratories to penetrate more than a few paces into the building, thus minimising the effects of wear, dirt, and noise.

The first floor carries a large L-shaped laboratory capable of accommodating a hundred students of the second and third year in individual work. On this floor there is also the honours laboratory with a capacity of about twenty students and a small lecture room capable of holding fifty.

The top floor contains a few rooms at the stair-head for general departmental use, the main floor space being given over to small research rooms, seventeen in number. In addition to the electrical and other services, a certain number of steady wall-supports consisting of monoliths built into the wall have been provided. Also horizontal sliding steel window shutters have been installed, similar to those in the lecture rooms but hand operated.

The simplest possible internal style has been adopted throughout the building, although a most pleasing effect has been attained in entrance, stairway, and corridors by clever arrangement of pillars, well-designed balustrades, and simple arches. The stairways and the floors of main corridors are in terazzo, but elsewhere Australian jarrow wood block has been generally chosen, the result being excellent in respect of cleanliness and comfort as well as appearance.

For convenience of upkeep and ease of replacement, all services have been placed so far as possible on wall and ceiling surfaces and have been coloured distinctively. For example, lighting electricity is yellow, town supply of water is aluminium, gas is black, and so on. Electrical services comprise 200 volts alternating supply at 50 cycles single phase and two-phase from the city mains for lighting and power, together with 110 volts d.c. from a generator set in the basement. In addition, there are two large capacity batteries each giving up to 120 volts and two smaller ones giving up to 1000 volts each. These supplies are taken to the lecture rooms and to the research rooms on both top floor and basement. For convenience in running temporary leads about the building, a vertical duct runs through the building in close proximity to the battery rooms. A small compressor in the basement supplies compressed air to research rooms and lecture rooms for blowpipes, small motors, cooling, and the like. Heating throughout the building is by radiators supplied with hot water from the University boiler house. A lift and the adequately equipped workshop complete the laboratory services.

There are three lecture rooms, seating 230,120 , and 50 respectively, the two larger ones being fitted with electrically operated steel window shutters of a simple type. Ventilation is by distant-control fan, and the fittings include specially designed roller blind blackboards; air-cooled projection lanterns sunk in the lecture tables, with inclined screens built permanently into the wall and facing the audience; floodlights (motor head lamps) for blackboards and lecture tables, and an adequate supply of electricity, gas, water, and compressed air. The control of all lecture room services has been centralised on the lecture bench itself, so that the lecturer or his assistant can deal on the spot with lantern, ventilation, shutters, and lighting.

In the teaching laboratories, simplicity of arrangement and fittings has been achieved by the provision of ordinary movable tables of a standard size, and fixing all water services to outside walls wherever possible.

In place of dark rooms for optical and other experiments requiring darkness, several sets of dark cells have been provided (similar to horse 'loose boxes'), so that numbers of students can work in close proximity to each other without mutual interference. In the main laboratories, vibration-free supports for galvanometers and other apparatus requiring steadiness have been provided by casting wide ferroconcrete collars round such pillars as have their foundations in the basement. Round these collars are fitted insulated stainless steel busbars connected to 25 volts alternating electric supply. This supply is taken through a new type of electric plug which adheres to the busbars by means of small permanent magnet contacts.

Although, at the date of writing, workmen are not yet out of the building, experience has shown the great convenience and effectiveness of the arrangements.

An opening function will take place on Feb. 18, when Sir William Bragg, one time occupant of the Cavendish chair of physics in the University, will be the principal speaker. 